\title{
Paniculitis subcutáneas en un hospital de tercer nivel: estudio retrospectivo de 113 casos
}

\author{
J. A. AVILÉS IZQUIERDO, C. RECARTE GARCÍA-ANDRADE ${ }^{1}$ R. SUÁREZ \\ FERNÁNDEZ, P. LÁZARO OCHAITA, M. LECONA ECHEVERRÍA², J. DE \\ PORTUGAL ÁLVAREZ ${ }^{1}$
}

\section{Servicios de Dermatología, ${ }^{1}$ Medicina Interna-II y de ${ }^{2}$ Anatomía Patológica. Hospital} General Universitario Gregorio Marañón. Madrid

\author{
SUBCUTANEOUS PANNICULITIS AT A THIRD LEVEL HOSPITAL: \\ RETROSPECTIVE STUDY OF 113 CASES
}

\section{RESUMEN}

Introducción: Las paniculitis o hipodermitis son un amplio y heterogéneo grupo de enfermedades caracterizadas por la presencia de nódulos subcutáneos inflamatorios localizados habitualmente en miembros inferiores.

Objetivos: Reflejar las características clínicopatológicas de los casos diagnosticados como paniculitis durante un periodo de 5 años; estudio epidemiológico de los pacientes, factores etiopatogénicos, evolución y tratamiento.

Material y métodos: Obtuvimos de forma retrospectiva los datos de 113 pacientes diagnosticados de paniculitis mediante informe histopatológico de biopsia cutánea realizadas entre los años 1997 y 2001.

Resultados: La proporción entre sexos fue de 4,65 mujeres por cada hombre. La edad media de los pacientes estudiados fue de $49 \pm 20$ años. El $100 \%$ tuvieron afectación en piernas, el 7,1\% en brazos, el $5,9 \%$ en tronco y el $0,9 \%$ en cara. El 9,7\% presentó fiebre y artromialgias, sobre todo en gente joven $(p<0,05)$. Los factores etiopatogénicos implicados fueron la tuberculosis, la faringoamigdalitis estreptocócica, la sarcoidosis y diversos fármacos. La forma histológica más frecuente fue la paniculitis septal sin vasculitis. El $24,8 \%$ no realizaron tratamiento; el $32,5 \%$ tomaron antiinflamatorios no esteroideos; el 31,6\% yoduro potásico; el $16 \%$ corticoesteroides orales y el 7,1\% tuberculoestáticos. La evolución de los pacientes fue buena en general e independiente del tratamiento realizado.

Conclusiones: Las paniculitis son un conjunto de enfermedades con clínica similar, pero muy heterogéneas en cuanto su etiología y hallazgos histopatológicos. Es más frecuente en mujeres y con clínica más expresiva en gente joven. Hasta en el 59,3\% de los casos se halló un agente etiológico causal. Estos factores coinciden con los publicados en otras series anteriores. Ante una sospecha de paniculitis, lo más eficiente es el diagnóstico clínico. Se debe realizar confirmación histológica mediante la realización de biopsia cutánea siempre que sea posible.

PALABRAS CLAVE: Clasificación. Eritema nodoso. Etiología. Paniculitis. Tratamiento.

ABSTRACT

Introduction: The panniculitides or hypodermitis are a wide and heterogeneous group of diseases characterized by the presence of subcutaneous inflammatory nodules located generally in low limbs.

Objetives: Show the clinicopathologic characteristics of the cases diagnosed as panniculitis for a 5 years period; their epidemiology, etiopathogenic factors, evolution and treatment.

Material and methods: A retrospective study of 113 patients diagnosed as panniculitis by histopathologic report of cutaneous biopsy since 1997 to 2001 were performed.

Results: The sex proportion was of 4.65 women to every man. The mean age of these patients was $49 \pm 20$ years old. $100 \%$ had legs affectation, $7.1 \%$ in arms, $5.9 \%$ in trunk and $0.9 \%$ in face. $9.7 \%$ presented fever and arthromyialgias, especially in young people $(p<0.05)$. The etiopathogenic factors implied were tuberculosis, streptococcic pharyngoamygdalitis, sarcoidosis and different drugs. The most frequent histological pattern was septal panniculitis without vasculitis. $24.8 \%$ did not realize any treatment; $32.5 \%$ took nonsteroideal anti-inflammatory drugs; $31.6 \%$ potassium iodide; $16 \%$ systemic corticosteroids and $7.1 \%$ tuberculostatic drugs. Evolution of the patients was good and independently from the treatment performed.

Conclusions: Panniculitides are a group of diseases with similar clinic, but very heterogeneous in their etiology and histopathologic findings. They are more frequent in women and with more expressive clinic in young people. Up to in the $59.3 \%$ of the studied cases a causal etiologic agent was identified. These factors are compatible with the published ones in other previous panniculitis series. When a paniculitis is suspected, the most efficient tool is the clinical diagnosis. Histological confirmation by cutaneous biopsy it must be done when it is possible.

KEY WORDS: Classification. Erythema nodosum. Etiology. Panniculitis. Treatment.

Avilés Izquierdo JA, Recarte García-Andrade C, Suárez. Fernández, R, Lázaro Ochaita P, Lecona Echeverría M, de Portugal Álvarez J. Paniculitis subcutáneas en un hospital de tercer nivel: estudio retrospectivo de 113 casos. An Med Interna (Madrid) 2004; $21: 108-112$. 